\title{
Dopamine in the pituitary adaptation to starvation in man
}

\author{
R.T. Jung, J. Rosenstock, S.M. Wood, G. Birch, R.A. Chalmers, K. Mashiter and \\ G.F. Joplin
}

Endocrine Unit, Royal Postgraduate Medical School, Hammersmith Hospital, London W12 OHS, UK.

\begin{abstract}
Summary: To investigate the role of the dopaminergic system in the pituitary adaptation to energy deprivation, the effect of metoclopramide, a dopamine receptor blocker, on prolactin (PRL), TSH, FSH and LH secretion was investigated in 6 healthy men in the fed state and at $36 \mathrm{~h}$ starvation. All underwent a further $36 \mathrm{~h}$ of starvation on a separate occasion to assess the effect of starvation on the TSH and PRL responses to TRH and the $L H$ and FSH responses to gonadotrophin releasing hormone (GnRH). In all subjects starvation produced the expected reduction in serum $\mathbf{T}_{3}$ and an average decrease of $53 \%$ in the cumulative TSH response to TRH. The basal serum PRL and its response to TRH and metoclopramide remained unchanged with $36 \mathrm{~h}$ starvation. The FSH response to $\mathrm{GnRH}$ also remained unchanged, but the LH response was significantly greater during starvation. We conclude that factor(s) other than dopamine influence not only thyrotrophic activity but also other aspects of pituitary function during energy deprivation.
\end{abstract}

\section{Introduction}

Starvation is associated with a decrease in serum triiodothyronine $\left(T_{3}\right)$ due to a reduction in $T_{3}$ production rate, the metabolic clearance rate remaining unchanged (Carlson et al., 1977; Chopra, 1977). Although the rate of thyroxine $\left(\mathrm{T}_{4}\right)$ production is also decreased on starvation, the serum $\mathrm{T}_{4}$ is maintained by the reduction in the rate of $T_{4}$ deiodination to $T_{3}$. Despite the fall in serum $\mathrm{T}_{3}, \mathrm{TSH}$ levels either remain unchanged or decrease on energy restriction (Carlson et al., 1977; Croxson et al., 1977; Pamblad et al., 1977; Vinik et al., 1974, 1975). There is a loss of TSH diurnal variation and a diminished TSH response to thyrotrophin releasing hormone (TRH) within $36 \mathrm{~h}$ of fasting (Croxson et al., 1977; Vinik et al., 1974, 1975). This is not due to an increased sensitivity of TSH secretion to the circulating thyroid hormones for the effect of exogenous $T_{3}$ in inhibiting TSH secretion is actually diminished within $48 \mathrm{~h}$ of starvation (Burger et al., 1980).

In rats, pituitary adaptation does not appear to be an intrinsic response since studies in vitro with pituitary slices from starved animals show a preservation of their response to $\mathrm{T}_{4}$ and $\mathrm{T}_{3}$ (Chopra et al., 1978). Likewise in man, it appears that starvation lowers pituitary thyrotrophic activity not by an intrinsic pituitary mechanism but by the increased effect of an inhibitory factor(s) which then act on the pituitary,

Correspondence: R.T. Jung M.A., M.D., M.R.C.P., University Department of Medicine, Wards 3/4, Ninewells Hospital and Medical School, Dundee DD1 9SY, UK.

Accepted: 23 January 1985 for if the fall in serum $\mathrm{T}_{3}$ concentration brought about by starvation is prevented by exogenous $\mathrm{T}_{3}$ the TSH response to TRH still becomes blunted (Gardner et al., 1979).

The report of Vinik et al. (1974) of a reduced prolactin (PRL) response to TRH on fasting might indicate increased dopaminergic activity on the pituitary in the early phases of energy restriction. It is also known that dopamine infusion will diminish not only the PRL response to TRH but also the TSH response (Scanlon et al., 1978). To investigate whether enhanced dopaminergic activity is responsible for this pituitary adaptation to starvation we have studied the effects of a dopamine receptor blocker (metoclopramide) on PRL secretion in healthy men in the 'fed' state and at $36 \mathrm{~h}$ of starvation. As LH release can be inhibited by dopamine we have also studied the LH and FSH response to GnRH in the fed and starved states.

\section{Subjects and methods}

Six healthy euthyroid males weighing $68.2 \pm 3.8 \mathrm{~kg}$ (mean \pm s.e.), an average $1.3 \%$ above ideal weight (Metropolitan Life Insurance Company, 1960) and aged $28.7 \pm 1.5 \mathrm{y}$ underwent $36 \mathrm{~h}$ of starvation on two separate occasions. On one occasion the subjects were given $10 \mathrm{mg}$ i.v. metoclopramide $\left(\right.$ Maxolon $^{\mathrm{R}}$ ) after an overnight fast (i.e. 'fed' state) and at $36 \mathrm{~h}$ of starvation. On another occasion the subjects underwent combined TRH $(200 \mu \mathrm{g})$ and GnRH $(100 \mu \mathrm{g})$ test again 
after an overnight fast and at $36 \mathrm{~h}$ of starvation. The protocol required the subject to fast initially from food and drink, except water, from midnight during the 'fed' state and at $0800 \mathrm{~h}$ undergo one or other of the tests. The subjects then ate normally. After an evening meal the subject starved, except for water, for $36 \mathrm{~h}$ when he then underwent the same test again at the same hour.

Blood samples were taken prior to intravenous TRH and GnRH and at 30,60 and 120 min afterwards. Blood samples for the metoclopramide test were taken at -15 and $0 \mathrm{~min}$ before and at $5,10,20$, $30,45,60,90$ and $120 \mathrm{~min}$ after injection. All test samples were measured for PRL, TSH, LH and FSH by specific radioimmunoassay (for methods see Kelly et al., 1978). Blood was also taken in the fed state and at $36 \mathrm{~h}$ starvation on both occasions and measured by radioimmunoassay (Kelly et al., 1978) for total $\mathrm{T}_{4}$ and $T_{3}$. Samples for a single subject were measured together in one assay. The mean intra-assay coefficient of variation was $7.7 \%$ for TSH, $7.2 \%$ for PRL, $9.0 \%$ for $\mathrm{LH}, \mathbf{6 . 0 \%}$ for $\mathrm{FSH}, 4.8 \%$ for $\mathrm{T}_{4}$ and $3.0 \%$ for $\mathrm{T}_{3}$.

Fully informed consent was given by each subject and the project was approved by the Royal Postgraduate Medical School and Hammersmith Hospital Ethical Committee. Statistical analysis was by the paired Student's $t$ test and significance is considered present if $P<0.05$. Values are given as mean \pm s.e. The results will be referred to as obtained in the 'fed' state representing overnight fast or in the 'starved' state representing $36 \mathrm{~h}$ starvation.

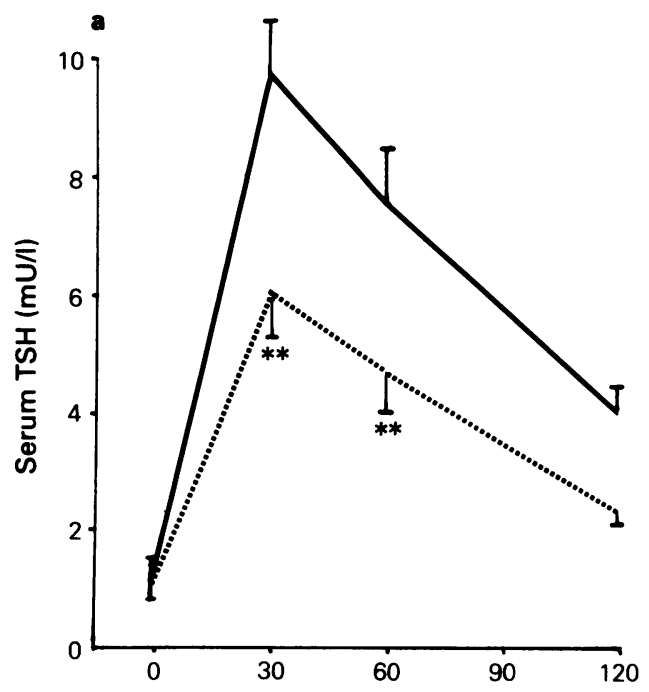

Table I Serum total $\mathrm{T}_{4}, \mathrm{~T}_{3}$ and basal prolactin (mean \pm s.e.) in fed state and at $36 \mathrm{~h}$ of starvation during the two separate occasions of starvation

\begin{tabular}{lcc}
\hline & 'Fed' state & 'Starved' state \\
\hline First occasion & & \\
$\quad$ Thyroxine nmol/1 & $110.0 \pm 8.3$ & $112.0 \pm 12.0$ \\
Triiodothyronine nmol/1 & $2.25 \pm 0.12$ & $1.90 \pm 0.13^{*}$ \\
Prolactin $\mu \mathrm{g} / \mathrm{l}$ & $7.9 \pm 0.8$ & $7.0 \pm 1.3$ \\
& & \\
Second occasion & & \\
Thyroxine nmol/1 & $104.5 \pm 6.3$ & $112.7 \pm 7.3$ \\
Triiodothyronine nmol/1 & $2.17 \pm 0.27$ & $1.73 \pm 0.11 \dagger$ \\
Prolactin $\mu \mathrm{g} / \mathrm{l}$ & $5.8 \pm 1.1$ & $6.1 \pm 2.2$ \\
\hline
\end{tabular}

Mean \pm s.e. significance of difference between fed and starved states; ${ }^{*} P=<0.01 ; \dagger P<0.02$.

\section{Results}

Starvation for $36 \mathrm{~h}$ did not alter the serum $\mathrm{T}_{4}$ but did produce a significant reduction in serum $\mathrm{T}_{3}$ on both occasions, falling on average to about $80 \%$ of basal (Table I). Starvation was associated with a significant decrease in the TSH response to TRH at all times studied (Figure 1) with an average cumulative decrease of $53 \%$ (fed $15.4 \pm 1.8$; starved $7.3 \pm 1.6 \mathrm{mU} / 1)$. Basal serum PRL levels and the PRL response to TRH were unaltered by $36 \mathrm{~h}$ of starvation (Figure 1). Although the mean incremental PRL responses to meto-

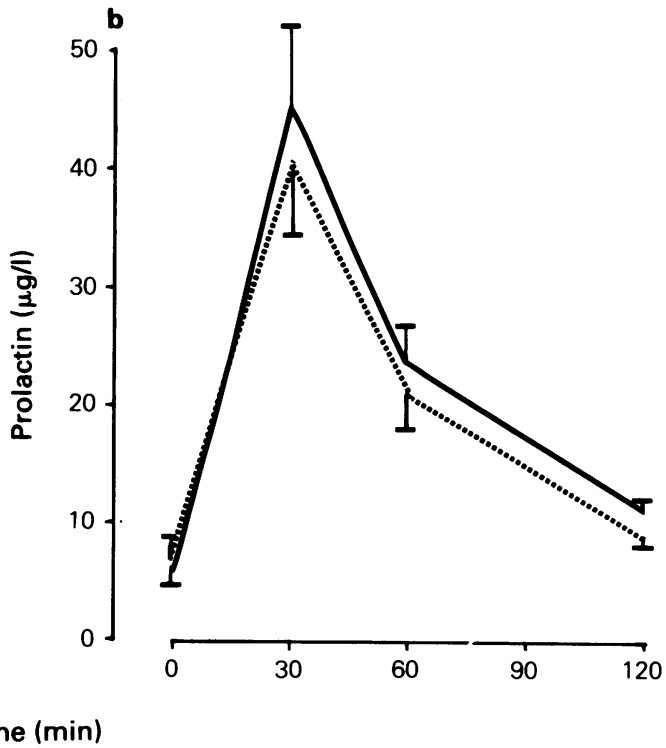

Figure 1 TSH (a) and PRL (b) responses to TRH in the fed state (-) and at $36 \mathrm{~h}$ of starvation (...). Mean \pm s.e. ${ }^{* *} P<0.01$. 


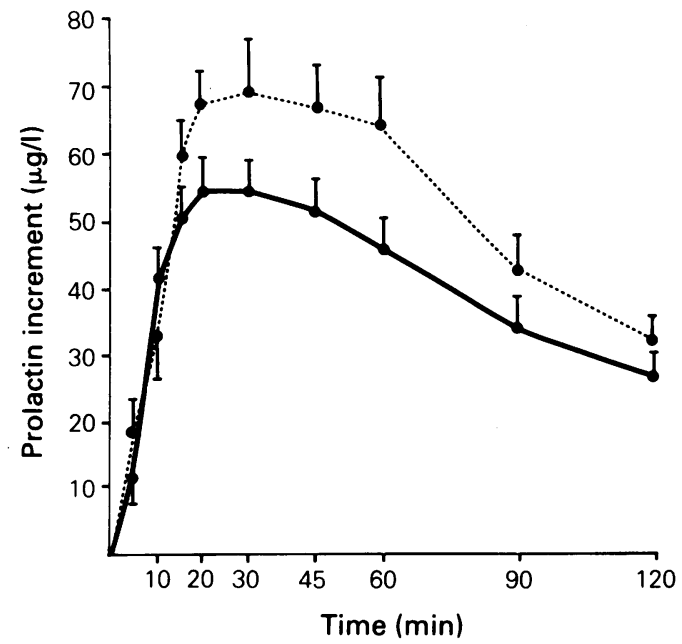

Figure 2 Incremental prolactin response to metoclopramide $(10 \mathrm{mg})$ in the fed state $(-)$ and at $36 \mathrm{~h}$ of starvation (...). At no single point in time after metoclopramide was the PRL increment significantly higher in the starved state. Mean \pm s.e.

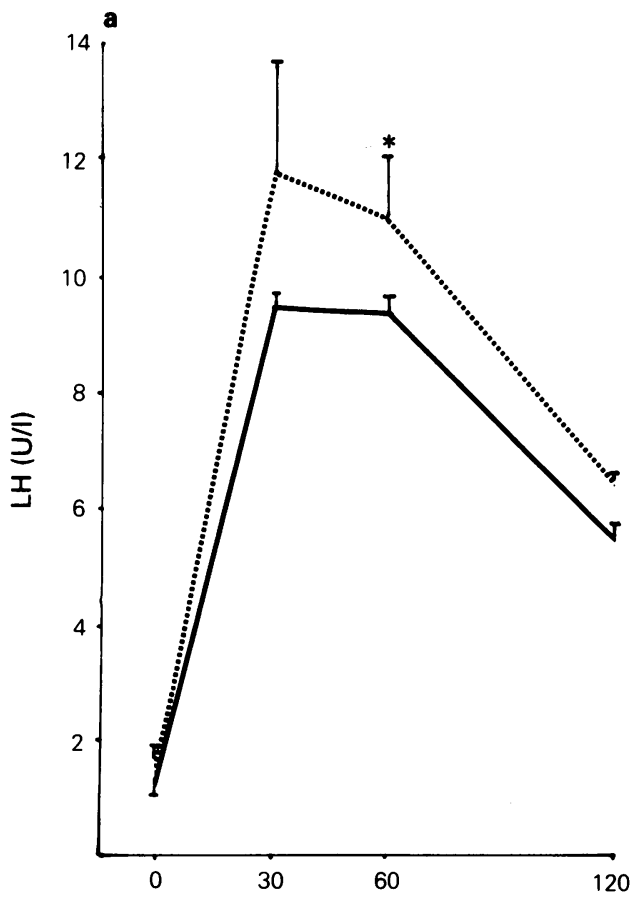

clopramide were higher in the starved state (Figure 2) this failed to reach significance at all the times studied. The $95 \%$ confidence limits were -5.5 to 33.3 for peak response. The TSH, FSH and LH responses to metoclopramide were so slight that no significant changes were noted on comparing the values obtained in the fed and starved states (data not shown).

The response of LH to GnRH was significantly greater in the starved state at the $60 \mathrm{~min}$ mark (Figure 3). However, serum FSH both basally and in response to GnRH (Figure 3) did not rise significantly with starvation.

\section{Discussion}

Our findings that starvation does not alter PRL basally or its response to TRH or metoclopramide would suggest that dopaminergic tone is not increased after $36 \mathrm{~h}$ starvation in man. The enhanced $\mathrm{LH}$ response to $\mathrm{GnRH}$ would also be in keeping with this as dopamine inhibits LH release (Judd et al., 1978). Our findings are, however, in marked contrast to that reported by Vinik et al. (1974) who found a reduction

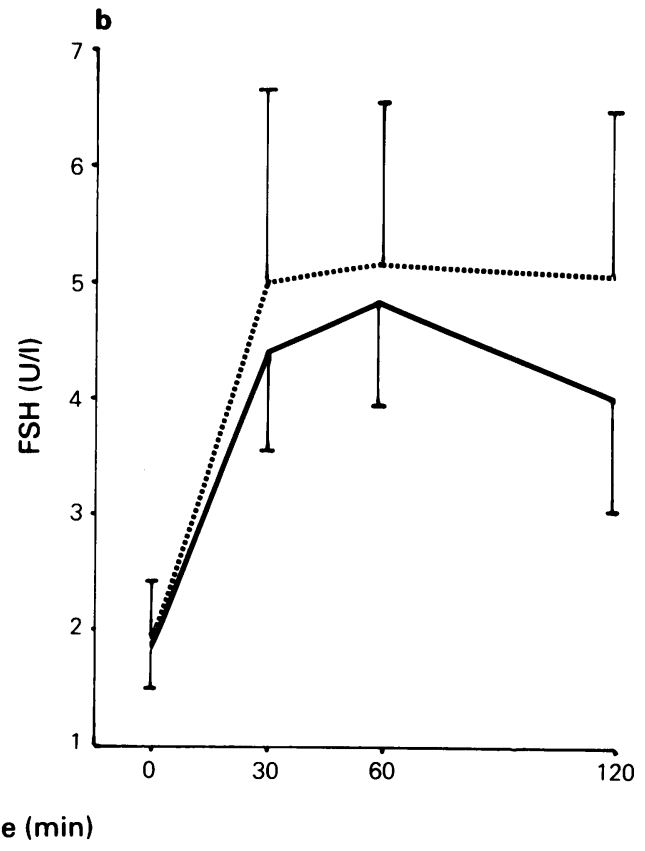

Figure 3 LH (a) and FSH (b) responses to GnRH in the 'fed' state (-) and at $36 \mathrm{~h}$ of starvation (...). Mean \pm s.e. $* P<0.02$ 
in the PRL response to $100 \mu \mathrm{g}$ of TRH in 9 male subjects after a similar period of fasting. Nevertheless, our findings are supported by the report of Burger $e t$ al. (1980) who also found no change in the PRL response to $200 \mu \mathrm{g}$ of TRH in both men and women at $48 \mathrm{~h}$ of starvation. Possibly the lower dosage of $100 \mu \mathrm{g}$ of TRH as used by Vinik et al. (1974) may account for this disparity of response.

It has been recently suggested that starvation might enhance peripheral dopaminergic activity as dopamine receptor blockade decreased the total ketone body levels in fasted rats (Belsa-Malpica et al., 1981). However, this may not apply to man or necessarily to all peripheral tissues in animals for the following reasons. Firstly, we have found that venous plasma dopamine concentrations in man actually show a slight decline on energy reduction (personal observation). Secondly, the neurotensin response to metoclopramide is blunted in the starved state and, thirdly, metoclopramide, which in the fed state causes an immediate decrease in insulin release, fails to do this if injected at $36 \mathrm{~h}$ starvation, suggesting that peripheral dopaminergic action on the islets is reduced

\section{References}

BELSA-MALPICA, G., JOHNSTON, D.G., BURRIN, J.M., ADUGH, C. \& ALBERTI, K.G.M.M. (1981). Dopaminergic control of ketogenesis in fasting. Clinical Endocrinology, $14,479$.

BIGGIO, G., PARCEDDU, M.L., FRATTA, W. \& GESSA, G.L. (1977). Changes in dopamine metabolism associated with fasting and starvation. In Advances in Biochemical Psychopharmacology, Costa, E. \& Gessa, G.L. (eds), p. 377. Raven Press: New York.

BURGER, A.G., WEISSEL, M. \& BERGER, M. (1980). Starvation induces a partial failure of tri-iodothyronine to inhibit the thyrotropin response to thyrotropin-releasing hormone. Journal of Clinical Endocrinology and Metabolism, 51, 1064.

CARLSON, H.E., DRENICK, E.J., CHOPRA, I.J. \& HERSHMAN, J.M. (1977). Alterations in basal and TRHstimulated serum levels of thyrotropin, prolactin and thyroid hormones in starved obese men. Journal of Clinical Endocrinology and Metabolism, 45, 707.

CHOPRA, I.J. (1977). A study of extrathyroidal conversion of thyroxine $\left(\mathrm{T}_{4}\right)$ to $3,3^{\prime} 5$-triiodothyronine $\left(\mathrm{T}_{3}\right)$ in vitro. Endocrinology, 101, 453.

CHOPRA, I.J., CARLSON, H.E. \& SOLOMON, D.H. (1978). Comparison of inhibitory effects of 3,5,3'-triiodothyronine $\left(\mathrm{T}_{3}\right)$ and 3,3'-diiodothyronine $\left(\mathrm{T}_{2}\right)$ on thyrotropinreleasing hormone induced release of thyrotropin in rat in vitro. Endocrinology, 103, 393.

CROXSON, M.S., HALL, T.D., KLETZKY, D.A., JARAMILLO, J.E. \& NICOLOFF, J.T. (1977). Decreased serum thyrotopin induced by fasting. Journal of Clinical Endocrinology and Metabolism, 45, 560.

GARDNER, D.F., KAPLAN, M.M., STANLEY, C.A. \& UTIGER, R.D. (1979). Effect of triiodothyronine replacement on the metabolic and pituitary responses to starvation. New with starvation in man (Wood et al., 1981). In animals, energy reduction also appears to be associated with an actual decrease in brain dopaminergic activity (Biggio et al., 1977). It, therefore, appears that there are other factors besides dopaminergic activity which are involved in the modulation of the thyrotropic-thyroidal axis in starvation and that these factors also affect other aspects of pituitary function. If this factor(s) could be found and its action reversed then it might be possible to prevent the fall in metabolic rate associated with energy restriction and thus enhance the weight loss of obese patients on energy restriction diets.

\section{Acknowledgements}

We thank all our volunteers. Dr K. Mashiter acknowledges the generous supply of reagents for the PRL and TSH assays from the National Pituitary Agency, NIAMDD, USA and technical assistance of Mr M.C. Sood and Miss H. Paul. Dr S.M. Wood is a British Diabetic Association R.D. Lawrence Research Fellow. Dr J. Rosenstock gratefully acknowledges support from the British Council and the Social Security System of Costa Rica.

England Journal of Medicine, 300, 579.

JUDD, S.J., RAKOFF, J.S. \& YEN, S.S.C. (1978). Inhibition of gonadotrophin and prolactin release by dopamine: effect of endogenous estradiol levels. Journal of Clinical Endocrinology and Metabolism, 47, 494.

KELLY, W.F., MASHITER, K., DOYLE, F.H., BANKS, L.M. \& JOPLIN, G.F. (1978). Treatment of prolactin secreting pituitary tumours in young women by needle implantation of radioactive yttrium. Quarterly Journal of Medicine, 47, 473.

METROPOLITAN LIFE INSURANCE COMPANY, NEW YORK. Statistical Bulletin (1960) 41, Feb. p. 6, March p. 7.

PAMBLAD, J., LEVI, L., BURGER, A., MELANDER, A., WESTGREN, U., voN SCHANCK, H. \& SKUDE, G. (1977). Effects of total energy withdrawal (fasting) on the levels of growth hormone, thyrotropin, cortisol, adrenaline, noradrenaline, $\mathrm{T}_{4}, \mathrm{~T}_{3}$ and $\mathrm{rT}_{3}$ in healthy controls. Acta Medica Scandinavica, 201, 15 .

SCANLON, M.F., REES SMITH, B. \& HALL, R. (1978). Thyroid-stimulating hormone: neuroregulation and clinical applications. Clinical Science and Molecular Medicine, $55,129$.

VINIK, A.I., KALK, W.J., MCLAREN, H. \& PAUL, M. (1974). Impaired prolactin response to synthetic thyrotropin-releasing hormone after 36 hour fast. Hormone and Metabolic Research, 6, 499.

VINIK, A.I., KALK, W.J., McLAREN, H., HENDRICKS, S. \& PIMSTONE, B.L. (1975). Fasting blunts the TSH response to synthetic thyrotropin-releasing hormone (TRH). Journal of Clinical Endocrinology and Metabolism, 40, 509.

WOOD, S.M., JUNG, R.T., ROSENSTOCK, J., LEE, Y.C. \& BLOOM, S.R. (1981). The effect of metoclopramide on plasma insulin and neurotensin in acute starvation. Diabetologia, 21, 516, Abstr. 71. 